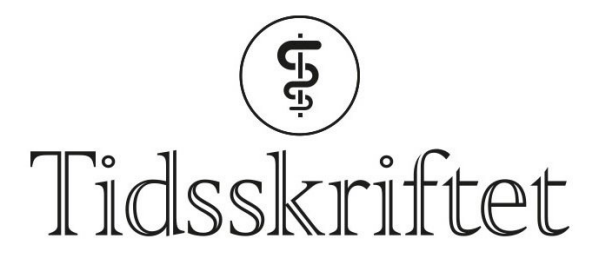

DEN NORSKE LEGEFORENING

\title{
Doktor dyregod
}

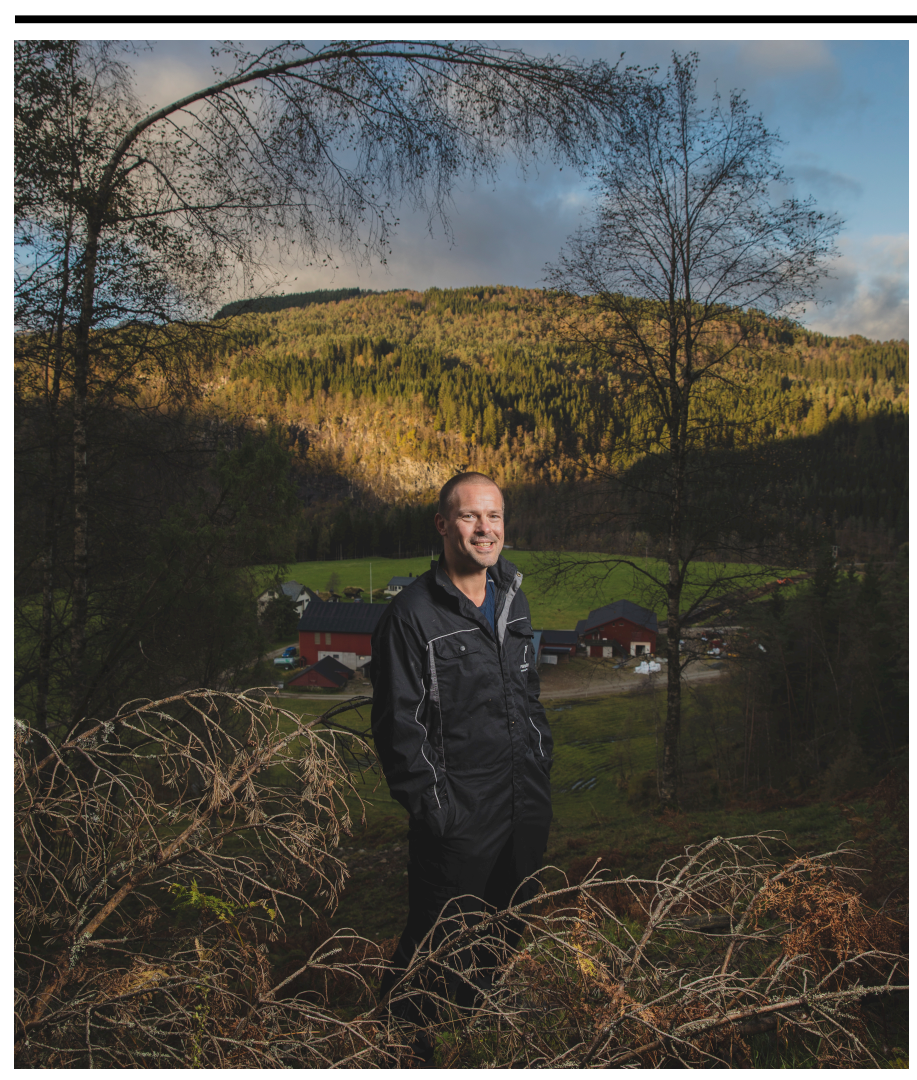

INTERVJU

MARTIN HOTVEDT

martin@hotvedt.no Universitetssykehuset Nord-Norge

Kommuneoverlege Øystein Furnes ville ikke kjøpe seg motorsykkel da han nærmet seg 40årskrisen. Han ville ha 24 storfe, familiegården og en splitter ny legevakt.

Kommuneoverlege Øystein Furnes cruiser lydløst i den nyinnkjøpte elbilen nedover fjellsiden inn mot tettstedet Førde i Sunnfjord.- Jeg har ikke sovet de siste nettene.

- Det var jo fullmåne i går, og det betyr høysesong for hjortejakt. Da må jeg ut. Sove får man gjøre siden, sier han.

Han peker inn mot den høstgule skogen.

- Der inne sto jeg for fire dager siden. Midt på natten, mens frostrøyken lå rundt meg. Fire meter fra en gigantisk kronhjort, som jeg dessverre ikke hadde løyve til å skyte. Det er sånt jeg lever for! 
Han blir stor i de brune øynene bare av å fortelle om det.

Det hele er som tatt ut fra en reklame for Vestlandet. Vi er omgitt av trange fjorder som skjærer seg inn mellom høye fjell. I skogene gjemmer både stor- og småvilt seg for den mildt sagt jaktinteresserte vestlendingen.

Nå er han på vei til, eller fra, jobb. Det kommer an på øyet som ser. 46-åringen, som er kommuneoverlege i Førde og sjef for den splitter nye legevakten der, er nemlig bonde resten av døgnet. Det var for noen år siden at han, kona og barna tok «det vanskeligste valget hittil i livet» og flyttet hjem.

Furnes hadde etablert seg som fastlege i Alta, hadde kone, to barn og tre vorstehere (!) - og var hodestups forelsket i landsdelen i nord.

- Jeg hadde det perfekt, egentlig. Holdt på å bli indremedisiner noen år tidligere og manglet bare halvannet år i gruppe 1-tjeneste før jeg var spesialist. Men så kom ungene og bikkjene, og jeg tenkte at allmennmedisin ville passe bedre. Og det gjorde det, jeg trivdes virkelig som fastlege i Alta. Men så ville jo skjebnen det annerledes, sier han.

\section{Norges fineste legevakt}

Vi kjører inn i sentrum av det tidligere arkitektonisk utskjelte tettstedet Førde og får se det 150 millioner kroner dyre hjertebarnet til Furnes åpenbare seg blant de småslitne 70tallsbygningene - et flunkende nytt bygg med lyse og luftige legekontorer, akuttrom, kommunale akuttsenger, overgrepsmottak og kort vei til sykehuset.

\section{Øystein Furnes}

Født i 1971 i Bergen

Cand.med. Universitetet i Bergen, 1998

Turnuslege Hammerfest sjukehus, 1999

Turnuslege Hammerfest kommune, 2000

Assistentlege Medisinsk avdeling Hammerfest sjukehus, 2000-05

Fastlege/legevaktsjef i Alta, 2005-12

Fastlege i Førde, 2012-15

Spesialist i allmennmedisin 2009/2014

Kommuneoverlege i Førde kommune fra 2015

Legevaktsjef i Førde fra 2012

Eier av Furnes Angus ENK fra 2012

«Legevakten for Sunnfjord og Ytre Sogn er Norges fineste, trolig verdens fineste», sa helseminister Bent Høie til NRK under åpningen i september.

Furnes gliser stolt med hele ansiktet når han forteller.

- Det er klart vi er fornøyd med et sånt sitat! Vi har jobbet hardt og målrettet med dette over flere år og ser det har gitt resultater.

En av Furnes' hovedoppgaver som nytiltrådt legevaktsjef og kommuneoverlege da han flyttet hjem var å bygge opp en ny legevakt som skulle betjene pasienter fra ni kommuner i Sogn og Fjordane. Han la spesielt vekt på å få spesialistene tilbake til legevakten.

- Før, da det var bare én lege på vakt sammen en sykepleier, så vi at legene helst ikke ville gå legevakt. De følte seg alene og utrygge. En gang fant vi en gråtende turnuslege på do en morgen etter en vakt. Forholdene var langt unna det optimale, sier han.

Vi går gjennom det gamle akuttmottaket inne på sentralsykehuset mens han forteller gråbrune vegger, oransje dører, gulaktig lys og ingen vinduer. Sykepleierne pleide visst å bli sjøsyke etter lange vakter her. 


\section{Seksdoblet utgiftene til legevakten}

- Det viktigste for meg var at vi fikk på plass en forsvarlig og funksjonell bemanning. Før var vi én lege med normaltarifflønn på vakt, nå har vi to fastlønnede leger på vakt hele døgnet. Og vi gikk fra to hjelpepersonellstillinger til 16. Før hadde vi $20 \%$ spesialistdekning på legevakten, nå er den på over 6o \%. Det skjedde noe over natten etter de endringene.

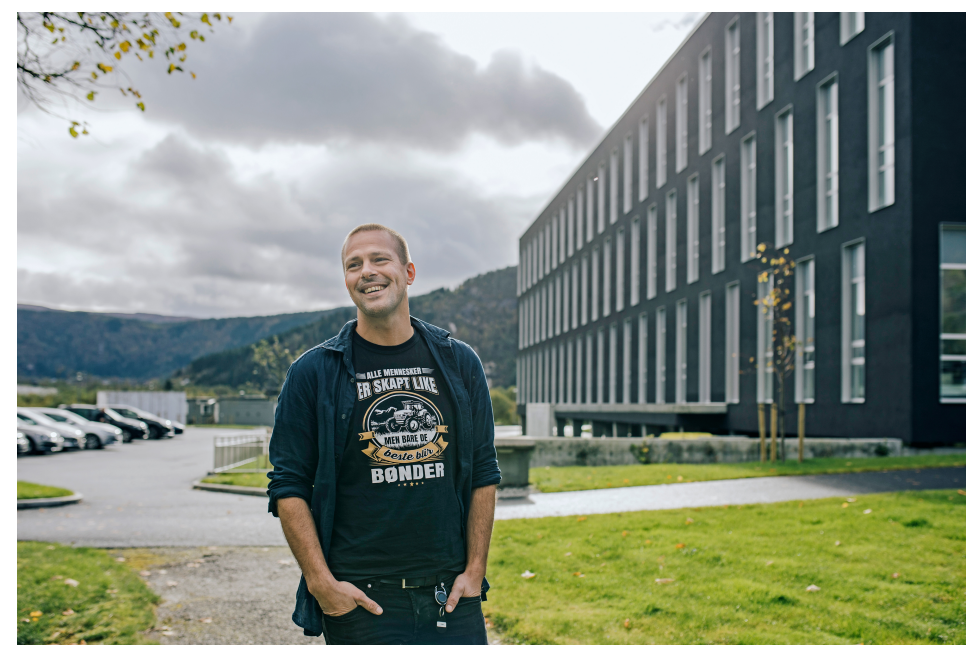

Men det har kostet penger, kan Furnes fortelle. På to år er driftsutgiftene til legevakten seksdoblet. En god investering, mener sjefen sjøl.

- Ja, det har vært dyrt, men dette er noe som har vært underprioritert i mange år. Heldigvis har de ni kommunene våre gått sammen i et forpliktende fellesskap og satser langsiktig på dette. Og det er viktig - for det er jo ofte på legevakten de store feilene skjer, sier han og lener seg tilbake i sofaen på det tomme venteværelset.

- Man kan ha uerfarne leger som går vakt, ting skjer fort, pasienten kommer tidlig i sykdomsforløpet - og er ofte da store feilene blir gjort. Skal vi klare å rekruttere folk inn i allmennpraksis, må de ha en vaktsituasjon som er håndterlig. Det vi ser etter å ha fått en god legevakt på plass, er at erfarne allmennleger søker seg hit. Det oppfattes som en trygg plass å jobbe, sier Furnes.

Han er ikke enig i debatten i diverse medier om at det er krise i norsk allmennmedisin.

- Det er ikke krise i norsk allmennmedisin, men ja - det er en del utfordringer. Hvis jeg skal komme med noen tips til klok legevaktdrift, bør kommunene øke bemanningen på sykepleiersiden og hvis mulig ha to leger på vakt samtidig - på fastlønn. Når det gjelder den daglige driften av legekontorene, mener jeg at en listelengde på 1 ooo pasienter holder, og at man kan tillate noen leger å ha delelister. Det gir fleksibilitet for ulike livsfaser, smiler han.

Fleksibiliteten er noe av det Furnes elsker ved jobben han har i dag - tre dager som kommuneoverlege, to dager som legevaktsjef. Mest jobb om vinteren, mindre på våren og om sommeren. Da er det dyrene som står i sentrum.

Han står opp klokken seks hver dag, tar en runde i fjøset, går inn igjen for en rask frokost før han kjører de to milene inn til rådhuset i Førde eller til legevakten, hvis han er der.

- Som sykehuslege eller fastlege hadde jeg nok ikke fått til dette, men fleksibiliteten var et krav for at jeg skulle ta jobben. Jeg måtte ha tid til dyrene, forklarer han.

\section{Fikk nevropatier av å rydde beite}

Vi kjører fra Førde tilbake til familiegården.

Han gestikulerer med høyre hånd og styrer med venstre. Peker på kulturlandskapet rundt oss. I tillegg til å drive sin egen mark leier han jord på fire nedlagte bruk i nærheten.

- Det har vært fysisk hardt å rydde alt dette. Heldigvis har jeg fått hjelp av sønnene mine. Da 
vi gikk i gang, måtte vi banke ned syv kilometer med gjerder på to måneder, sier han mens han peker på det omliggende lappeteppet av beitemark.

Han legger til:- Jeg husker et par dager på legekontoret hvor jeg hadde nevropatier i begge hendene etter all jobbingen. Mistet utstyr på gulvet og sånn. Da lo pasientene, smiler han.

\section{Ville alltid tilbake}

Furnes bestemte seg allerede i ungdommen for at han en dag skulle tilbake til gården.

- Jeg var klar på at jeg kom til å overta driften av gården om ingen andre av søsknene mine ville. Det sa jeg allerede som 15-åring, da jeg flyttet hjemmefra for å gå på folkehøyskole. Dette bruket måtte drives videre, sier han bestemt.

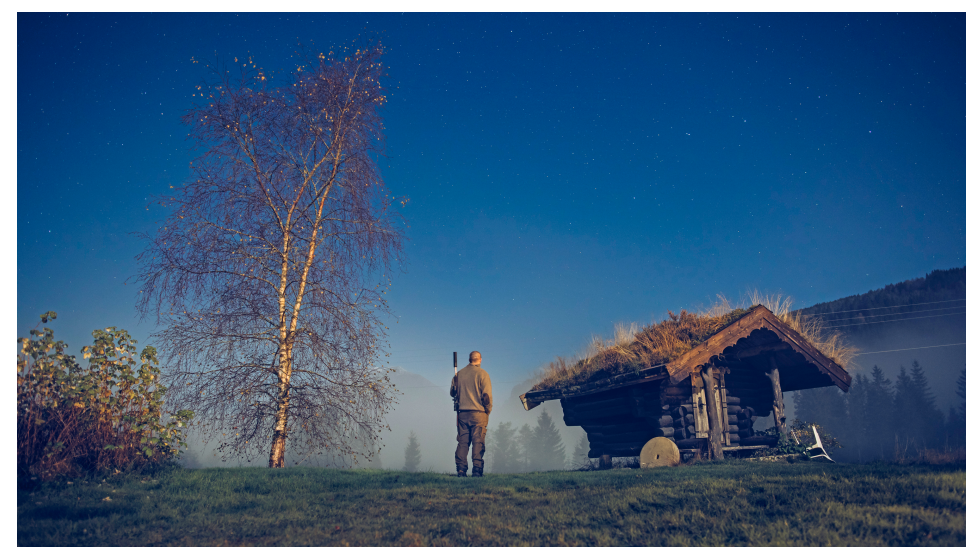

Med faren som forbilde - også han hardtarbeidende allmennlege og bonde - returnerte Furnes med familie for å overta som syvende generasjon gårdbruker i 2012.

- Du kan sikkert si jeg var inspirert av far. Jeg vokste jo opp med ham og så det livet han levde. Det virket spennende, hektisk og givende. Han var mye borte, men jeg så at han trivdes.

Furnes husker fortsatt at han måtte bli med om bord i legeskyssbåten og fiske torsk mens faren gikk i land for å undersøke pasienter på forblåste øyer. - Det gjorde inntrykk, smiler han.

Vi parkerer bilen på gårdsplassen.

Furnes-gården ligger på en ås like ved tettstedet Bygstad i Gaular kommune. Gården lå brakk i 200 år etter svartedaudens herjinger på 130o-tallet, men har vært i kontinuerlig drift siden 1500 -tallet. I dag ruver en moderne og stor logo av stein i betongveggen på fjøset. Store bokstaver: Furnes Angus.

Her driver kommuneoverlegen kjøttproduksjon med rasen aberdeen angus, ikke melkeproduksjon, som generasjonene før ham gjorde.

- Vi driver salg direkte til privatkunder og restauranter, så ja, vi prøver å drive business, og dette er nøye regnet på. Dette er noe vi skal prøve å tjene på - hvis ikke hadde vi ruinert oss selv, forklarer Furnes.

\section{Leies inn som kokk og guide}

Et par hundre meter opp i veien driver kompisene hans, Steinar Sørli og Yngve Brakstad, det luksuriøse overnattingsstedet Villa Åmot i en totalrenovert sveitservilla på et tun fra 1890. Her har russiske forretningsmagnater og amerikanske millionærer bodd for å få oppleve noe særegent.

- Det at de gutta oppi veien satser så hardt på turisme, og at det går bra for dem, var også en faktor som gjorde at jeg hadde tro på å flytte hjem og drive kjøttproduksjon, forklarer Furnes.

På hjemmesiden til Villa Åmot kan man leie inn Furnes som kokk eller guide i 
lokalområdet. - Hvis de for eksempel har grupper på kurs eller bryllupsferie der oppe, hender det at jeg tar med noen kjøttstykker opp, forteller litt om driften min - og lager mat til dem, forklarer han, og legger til:

- Jeg er blitt god til å steke kjøtt, men så mye mer kan jeg ikke!

Kommuneoverlege, legevaktsjef, bonde og kokk, altså.

Nå tar han de siste kursene for å bli godkjent spesialist i samfunnsmedisin. Kolleger lurer på om han sover i det hele tatt.

- Jeg har alltid vært interessert i mye forskjellig.I jobben som kommuneoverlege treffer jeg mange andre yrkesgrupper, for eksempel jurister, rådgivere og økonomer, og det tvinger meg til å tenke bredt og annerledes. Det er noe jeg liker.

- Hvordan får du tid til alt?

- Jeg har i perioder veldig stor arbeidskapasitet. Og så kjenner jeg meg selv godt. Når jeg føler at det blir for mye, roer jeg litt ned. Da tenker jeg at jeg driver med det jeg må, og ingenting mer.

Han tar en pause. Drar fingrene over det kortklippede håret.

- Det er ingen depresjon, heller en følelse av å ha lite overskudd. Da tar jeg det litt rolig, og så er overskuddet tilbake. Man er jo blitt kjent med seg selv.

- Får du tid til pasienter innimellom?

- Ja, jeg går noen legevakter hver måned. Det er jo en risiko at jeg med dette livet mister litt klinisk erfaring. Men jeg følger godt med, leser en del artikler og holder meg oppdatert. Så får jeg se hva det blir til etter hvert. Jeg har alltid vært veldig glad i klinikken og trodde jeg skulle bli der til evig tid. Men nå er situasjonen endret, og jeg er avhengig av fleksibiliteten. Jeg har jo jobbet klinisk i 20 år. Og så tenker jeg at det er en tid for alt.

- Hva gjør du for å koble av?

- Leser en bok, trener, jakter. Det vanlige. Å jakte lærte jeg meg da jeg kom til Finnmark som turnuslege. Da slo naturinteressen ut i full blomst, sier han.

\section{Traumetrening på legevakt}

Selv om man skulle tro at Furnes skulle si seg fornøyd med å ha fått opp den angivelig flotteste legevakten i landet, ligger han ikke på latsiden.

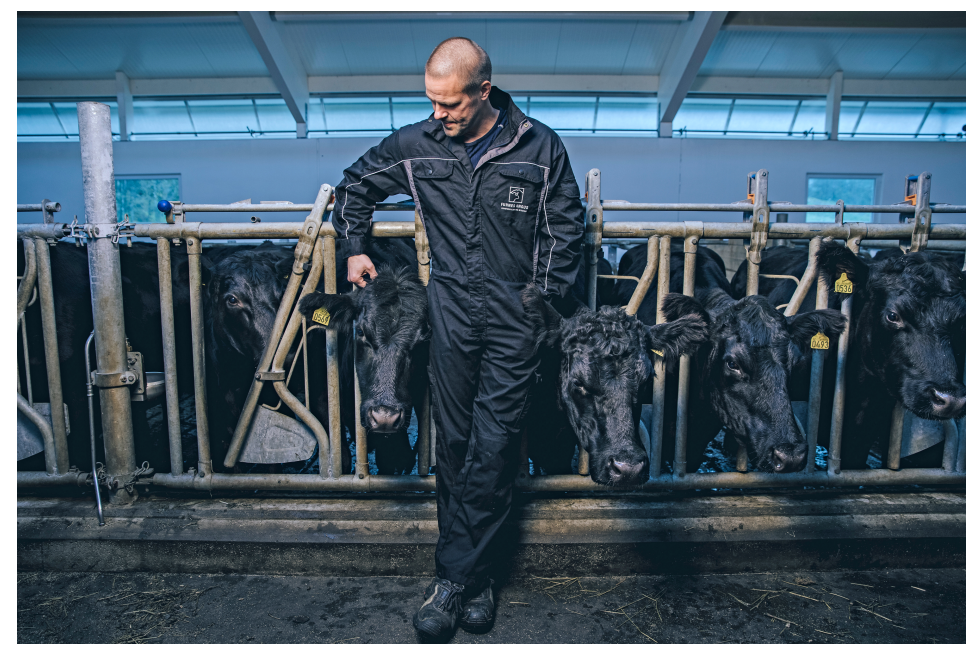

- Hva blir det neste?

- Vi er ikke i mål med legevakten. Man kan alltid bli bedre. Det neste jeg har lyst til å få til, er BEST-prosjektet med inspirasjon fra Alta - bedre og systematisk teamtrening. Det må vi få til i hele fylket, sier han engasjert.

Furnes prater alltid fort og lenge. 
Vi skulle egentlig få omvisning på gården, men blir stående inne i fjøset mens han fortsetter:

- Det å løse problemet rundt de små kommunene blir også viktig. Legevaktene sentraliseres, og selv om det har gitt mange kvalitetsløft, har det flyttet helsetjenesten langt unna de små kommunene. Hvordan skal vi klare å hjelpe innbyggerne der på en god måte?

Helsedirektoratet er interessert i å kjøre et pilotprosjekt på en annen måte å tenke legevakt på. Det er mulig vi blir med på det. Det innebærer forskjellige nivåer av legevakt som man plasserer rundt i mindre kommuner - helsevakt i stedet for legevakt - bemannet med sykepleiere. Det kan være noe for periferien i fremtiden. Jeg synes sånne nye ideer er spennende og liker å høre hva andre folk og yrkesgrupper rundt meg har å si, sier han.

- Selv om vi medisinere er forskjellige, er vi samtidig ganske snevre. Hvis du har vært på en legefest en gang, skjønner du hva jeg mener, sier han.

Han nikker bort mot den 1 ooo kilo tunge avlsoksen Inge.

- Det er mye annet som er spennende.

Publisert: 12. desember 2017. Tidsskr Nor Legeforen. DOI: 10.4045/tidsskr.17.o934

(C) Tidsskrift for Den norske legeforening 2020. Lastet ned fra tidsskriftet.no 